\title{
Recent Records of Alien Anurans on the Pacific Island of Guam ${ }^{1}$
}

\author{
Michelle T. Christy, ${ }^{2,3}$ Craig S. Clark, ${ }^{4}$ David E. Gee II, ${ }^{5}$ Diane Vice, ${ }^{5}$ Daniel S. Vice, ${ }^{4}$ \\ Mitchell P. Warner, ${ }^{6}$ Claudine L. Tyrrell, ${ }^{3,7}$ Gordon H. Rodda, ${ }^{8}$ and Julie A. Savidge ${ }^{3}$
}

\begin{abstract}
Eight anuran species were recorded for the first time in Guam in the period May 2003-December 2005, all apparently the result of arrivals to the island since 2000. Three of the eight species (Rana guentheri, Polypedates megacephalus, and Eleutherodactylus planirostris) had well-established breeding populations by 2005. A further three (Fejervarya cf. limnocharis, Fejervarya cancrivora, and Microbyla pulchra) were recorded from a number of individuals, but it is not known whether these species have established breeding populations. Two species (Kaloula pulchra and Eleutherodactylus coqui) appear to be incidental transportations to the island that have not established. Before 2003, five anuran species, all introductions, had been recorded from Guam. Three of these, Polypedates leucomystax, Pseudacris regilla, and Kaloula picta, were detected on Guam in incoming cargo but destroyed. Two species established: Bufo marinus was deliberately introduced and the Australian hylid Litoria fallax was probably an accidental introduction. Successful establishment of anurans on Guam has increased the risk of frog introductions to nearby islands. By providing additional food sources for the brown tree snake (Boiga irregularis), anuran introductions have increased the chance that $B$. irregularis might substantially increase in numbers and in turn increase the risk of the snake being accidentally transported to other islands.
\end{abstract}

\footnotetext{
${ }^{1}$ Funding for this project was provided by the Department of the Interior's Office of Insular Affairs and Fish and Wildlife Service. Manuscript accepted 19 October 2006.

${ }^{2}$ Corresponding author (phone: 671-355-4017; fax: 671-355-4016; e-mail: shell@lamar.colostate.edu).

${ }^{3}$ Department of Fish, Wildlife, and Conservation Biology, Colorado State University, Fort Collins, Colorado 80523.

${ }^{4}$ U.S. Department of Agriculture, Wildlife Services, 1060 Army Drive, Suite 103C, Barrigada Heights, Guam 96913.

${ }^{5}$ Guam Department of Agriculture, Division of Aquatic and Wildlife Resources, 163 Dairy Road, Mangilao, Guam 96923.

${ }^{6}$ In-Depth Photography, P.O. Box 20578 G.M.F., Barrigada, Guam 96921.

${ }^{7}$ Current address: 58 Gladstone Road, Dalmore, Dunedin, New Zealand.

${ }^{8}$ U.S. Geological Survey, Fort Collins Science Center, 2150 Centre Avenue, Building C, Fort Collins, Colorado 80526.
}

Pacific Science (2007), vol. 61, no. 4:469-483

(C) 2007 by University of Hawai'i Press

All rights reserved
INVASIVE ORGANISMS impact recipient communities in a number of ways, perhaps the most important being the modification of the trophic structure within the community (e.g., Fritts and Rodda 1998, Short et al. 2002, Moore et al. 2004). Island endemics that have evolved in the absence of certain alien predators may be particularly vulnerable because they lack the necessary defenses to impede their predation (Case and Bolger 1991, Dickman 1996, Fritts and Rodda 1998). Alternatively, the influx and successful establishment of nonindigenous prey may increase food availability for a number of species already present (e.g., Pimm 1987, Rodda and Fritts 1992, Burnett 1997, Poulin et al. 2001). If there is a lack of niche differentiation in environments where invasive and native species share common resources, the resultant competitive exclusion of the weaker species may cause extirpation of endemics (Rosenzweig and MacArthur 1963, Rosenzweig 1981, Cadi and Joly 2003). Invasive species can destroy or modify crucial habitat, leading to elevated levels of exposure of endemics to 
predators, competition for food resources, or removal of important refuge attributes (Costin and Moore 1960, Paulay 1994, Priddel and Carlile 1998). Pest animals are also often vectors for the spread of pathogens and disease (Geering et al. 1995, Dickman 1996). Furthermore, if predator control methods are established, the resulting effect on native nontarget species can be considerable (Belcher 1998, Eason et al. 1999, Marks et al. 2000).

Guam, situated in the western Pacific Ocean $\left(13^{\circ} 25^{\prime} \mathrm{N}, 144^{\circ} 45^{\prime} \mathrm{E}\right)$, is renowned for the introduction of a number of nonindigenous vertebrate species over the past century, including the brown tree snake (Boiga irregularis) (Savidge 1984, 1987, Fritts and Rodda 1998). McCoid (1993) listed 17 extralimital species of reptiles and amphibians, of which nine are known to have established populations, and later estimated that $43 \%$ of Guam's nonmarine herpetofauna were nonindigenous (McCoid 1999). Wiles (2000) documented an additional six reptile and one amphibian species, all of which were single specimens and unlikely to have established populations.

Of the five anuran species known to have been introduced to Guam before 2003, only two established breeding populations (Eldredge 1988, McCoid 1993, McCoid and Kleberg 1995, Wiles 2000). The marine toad (Bufo marinus) was intentionally imported as a biocontrol agent for insects and the black slug (Veronicella leydigi) in 1937 (Anon. 1940, Chernin 1979), and the eastern dwarf tree frog (Litoria fallax) was introduced from Australia around 1968 via an unknown vector (Eldredge 1988). The three species that failed to establish appear to be introductions of one or two individuals in cargo: Kaloula picta from the deck of a ship (McCoid 1993), Polypedates leucomystax in an aircraft (Wiles 2000), and Pseudacris regilla on imported Christmas trees (McCoid 1993) and more recently (2005) on produce originating from the mainland United States (Guam Division of Aquatic and Wildlife Resources, unpubl. data). By 2005 , an additional eight anuran species were identified on Guam, of which at least three are recognized as established. Here we docu- ment these new introductions and discuss their potential impacts to Guam and neighboring islands.

\section{MATERIALS AND METHODS}

Occurrence records of the new nonindigenous frog species on Guam were obtained from reports and specimens brought in by the public and wildlife personnel, opportunistic field collection, and targeted field surveys carried out by U.S. Geological Survey, Colorado State University, and U.S. Department of Agriculture, Wildlife Services staff between 2003 and 2005.

RESULTS

\section{Established Species}

Eleutherodactylus planirostris Cope, 1862 (Family Leptodactylidae), Greenhouse Frog

This species was first detected at St. John's School, Tumon (21 October 2003), when reports were made of numerous "small frogs" on the school grounds. Surveys (22-29 October 2003) to delimit the population confirmed a well-established population in $\mathrm{Tu}-$ mon (Figures 1 and $2 A$ ), with juveniles and calling adults recorded. The species has since been found in Tamuning, Mangilao, and Manengon. The direct development of frogs from eggs laid under damp vegetation or debris (Schwartz 1974) makes detection of eggs of this species difficult, and they have yet to be found on Guam.

Originally from the Caribbean islands of Cuba, the Bahamas, and the Caymans, the greenhouse frog has been introduced to Florida, Louisiana, Hawai' $i$, and Jamaica (Kraus et al. 1999, Kraus and Campbell 2002). Hawai'i is the suspected source of the Guam population, because the areas first colonized were supplied with ornamental plants from Hawai'i.

Polypedates megacephalus Hallowell, 1861 (Family Rhacophoridae), Hong Kong Whipping Frog

The species was initially detected as a breeding population in ponds north of Dan- 


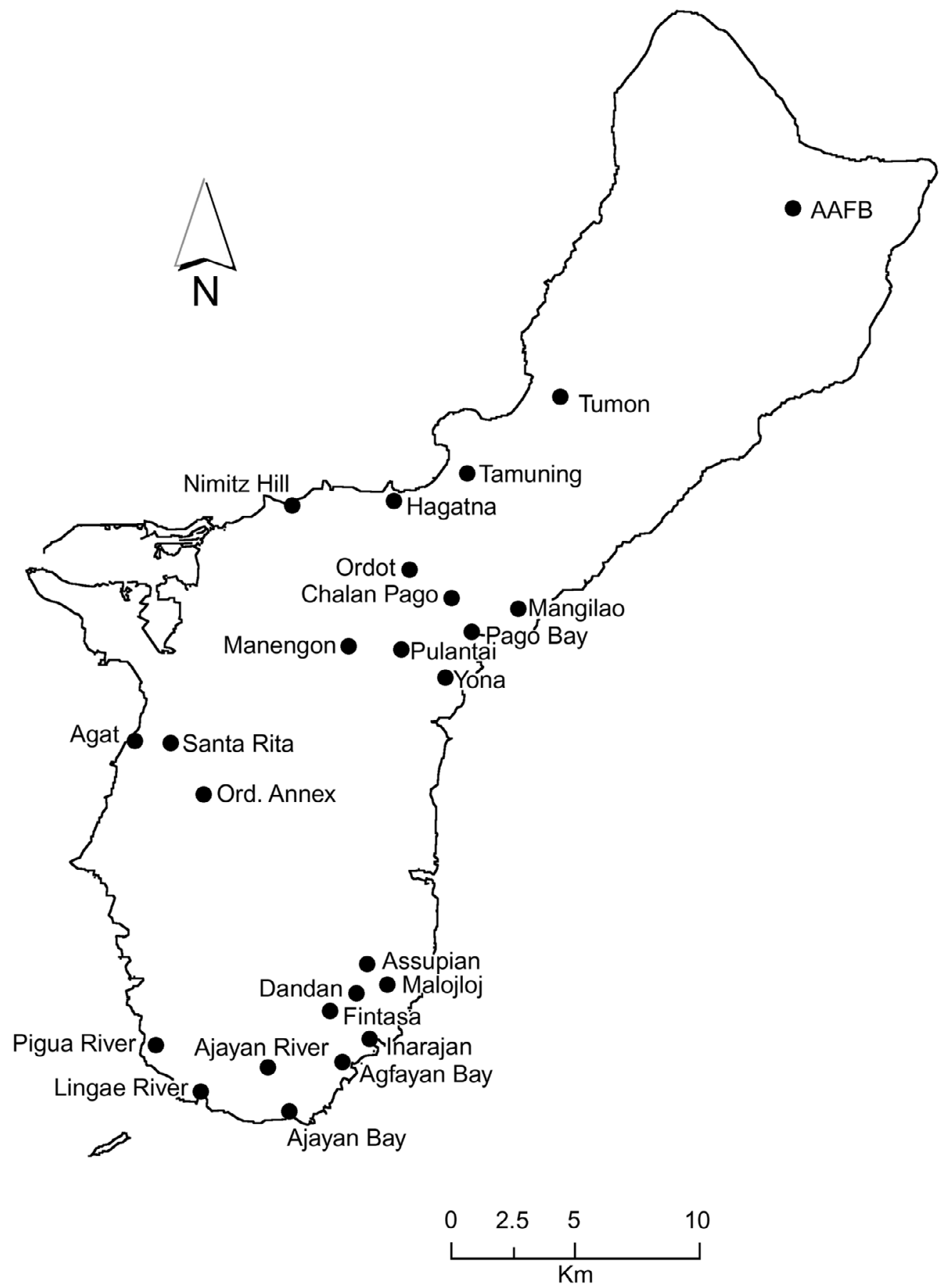

FIgUre 1. Map of Guam showing locations mentioned in the text. AAFB, Andersen Air Force Base; Ord. Annex, COMNAVMAR Ordnance Annex. 


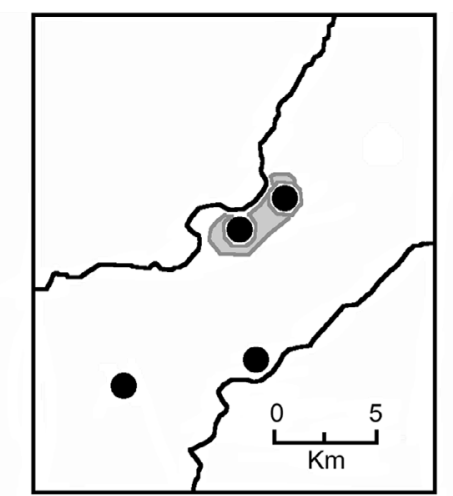

A

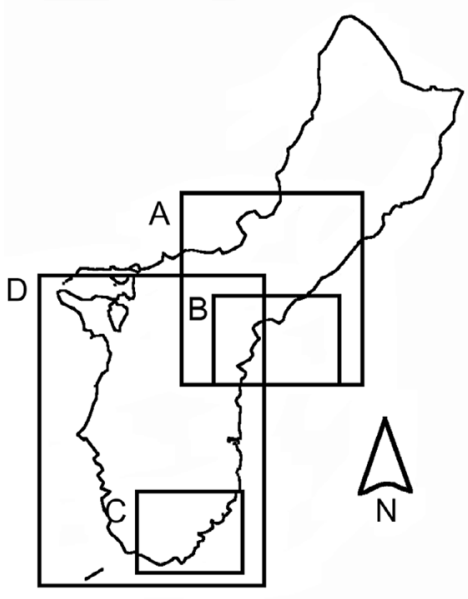

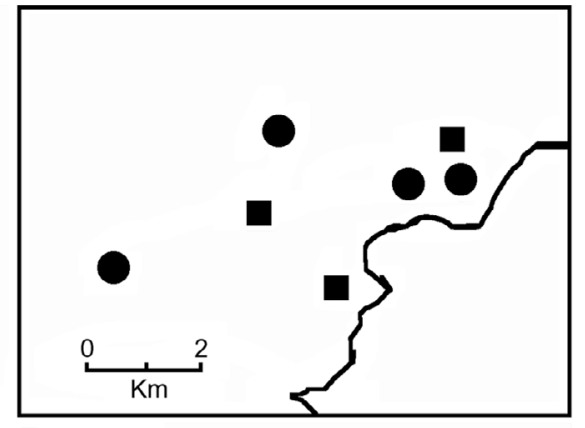

B
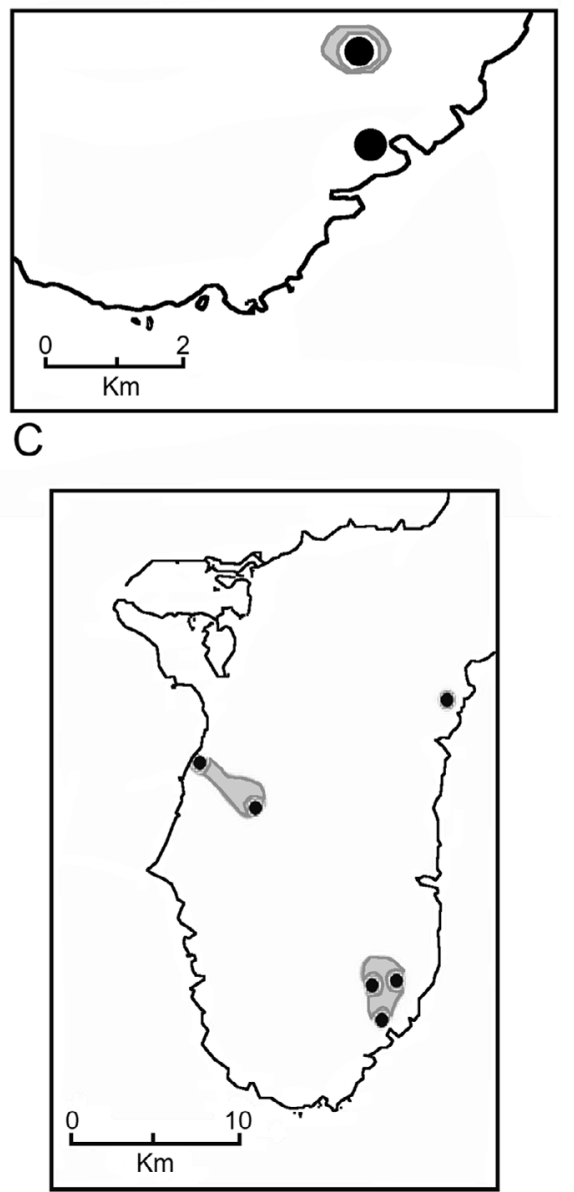

$\mathrm{D}$

Figure 2. Map showing the known locations of five of the eight frog species discovered on Guam to December 2005: A, Eleutherodactylus planirostris; B, Fejervarya cancrivora (•) and F. cf. limnocharis (ם); C, Microbyla pulchra; and D, Polypedates megacephalus. Solid symbols represent collection locations and shaded areas illustrate the current range of the species based on these and additional observations. Specimens with unknown collection location are not included. 
dan (22 January 2004). Foam nests containing 300-400 eggs each were found in shallow, still water, typically attached to emergent vegetation. The species has since been collected or reported breeding from Agat, Malojloj, Inarajan, Yona, and COMNAVMAR (Commander Naval Forces Marianas) Ordnance Annex (Figures 1 and 2D). The Guam population has both forms of anterior dorsal surface coloration and pattern ( $\mathrm{x}$ shaped marking and four longitudinal stripes) that are typical within-population variation in P. megacephalus (H. Ota, University of the Ryukyus, pers. comm.).

Polypedates megacephalus is distributed in southern China, Taiwan, Tibet, and northern India (Zhao and Adler 1993).

Rana guentheri Boulenger, 1882 (Family Ranidae), Günther's Amoy Frog

An established population was detected in Inarajan (Figure 1) by the owner of an aquaculture farm (6 May 2003). Two adults were collected on a riverbank adjacent to the fish farm ponds, and tadpoles were collected from the fish ponds. Subsequently, a large number of frogs was hand captured and eggs and larvae removed from nearby ponds at Dandan, at the same location Microbyla pulchra and $P$. megacephalus were first detected. However, opportunistic observations by one of the authors (M.P.W.) suggest that the species has been present in the area since at least 2001, and reports by residents indicate that it was present for several years before being detected at the Inarajan fish farm. Residents have reported hearing small choruses initially from ponds around Malojloj, Ajayan Bay, and Agfayan Bay in June 2001, and over a much wider area following Supertyphoon Pongsona in December 2002. Near the Lingae River a resident noted choruses in November 2003, and by March 2004 a population was established in the area. By December 2005 this species was also detected in Santa Rita, Agat, COMNAVMAR Ordnance Annex, Assupian, Fintasa Falls, the Ajayan River, and the Pigua River, and there are unconfirmed reports of it being present at Chalan Pago, Ordot, Mangilao, and Hagåtña. Dry land dispersal to high points distant from water, such as Mount
Alutom (near Nimitz Hill), has also been observed. Rana guentheri's range has expanded rapidly (Figure 3), and it now appears to be established broadly over southern Guam north to Pago Bay and Nimitz Hill. The species is locally known as the "barking frog" because of its distinctive call and was the first of the recent frog introductions to be detected.

Rana guentheri is distributed throughout southern China north to Hong Kong and the Yangtze River. It is also common in Hainan, Taiwan, and central Vietnam (Frost 2004), and populations exist in Laos (Orlov et al. 2002).

\section{Species of Questionable Status}

Fejervarya cancrivora Gravenhorst, 1829 (Family Ranidae), Crab-Eating Frog

The species was first recorded from a specimen collected at the University of Guam's Marine Laboratory (5 November 2003), within $500 \mathrm{~m}$ of the university's aquaculture facility at Fadian Point, near Mangilao (Figure 1). It was presented to Guam Division of Aquatic and Wildlife Resources. A second specimen was brought to Guam Division of Aquatic and Wildlife Resources almost a year later (13 September 2004); no collection information for the specimen was available except that it was found in "southern Guam." These first two specimens were initially identified as belonging to the Rana nigromaculata complex. A third specimen, also from "southern Guam," was collected on 27 January 2005, and it was at this point that the correct identity of the previous two specimens of F. cancrivora was determined. Over the next 10 months the species was located at an additional four sites (Figure 2B)-Mangilao: two specimens collected, one behind the Ordot School (9 May 2005) and one in a damp swale (12 May 2005); Pulantat, near Yona: a single individual (10 November 2005) caught in a damp swale (J. Cepeda, pers. obs.); Manengon: a single individual (13 November 2005) found in a roadside puddle approximately $400 \mathrm{~m}$ from a golf course. The breeding status and range of the species is unclear.

Fejervarya cancrivora is native to Southeast Asia, including the southeastern part of 

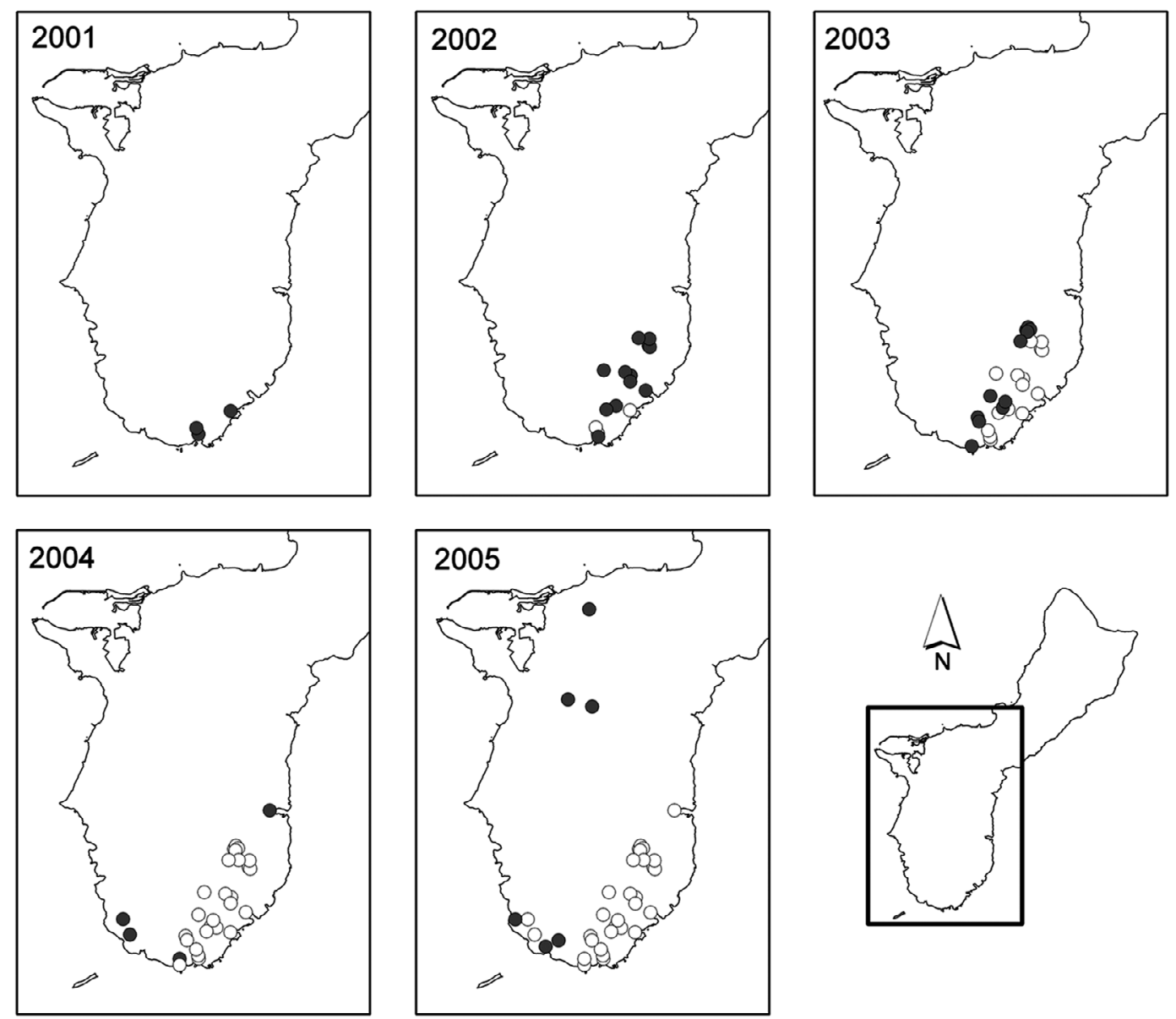

Figure 3. Distribution and range expansion on Guam of Rana guentheri since its discovery in June 2001 to December 2005. Each map shows the total cumulative number of localities from 2001 to that year. $\bullet$, locations discovered for the first time in that year; $\bigcirc$, locations discovered in previous years. Rana guentheri was first found at two aquaculture facilities in southern Guam.

China, Indonesia, Malaysia, Myanmar, Singapore, Thailand, and Vietnam (Dubois and Ohler 2002, Sumida et al. 2002). Introduced populations of the species are present in New Guinea (Menzies 1996) and perhaps the Philippines (Brown and Alcala 1970).

Fejervarya limnocharis sensu lato Gravenhorst, 1829 (Family Ranidae), Rice Frog

A second Fejervarya species, Fejervarya limnocharis sensu lato was recorded from three sites within $5 \mathrm{~km}$ of each other along the east coast of central Guam. Initially a single spec- imen was collected from Yona (Figure 1) at a plant nursery (3 November 2003). An unsubstantiated report from the nursery owner stated that it had been unintentionally transported to that location from another plant nursery in Inarajan. The specimen was photographed but accidentally destroyed during preservation. At the second site, Pulantat, a pair was observed in amplexus (24 January 2004), and at Mangilao (5 June 2005) an individual was found calling in an aquaculture pond used to stock tilapia (Oreochromis sp.) for a period of $5 \mathrm{yr}$ before being abandoned 
in 2002 (Figure 2B). The owner of the pond reported the "same species" calling each rainy season for at least $3 \mathrm{yr}(2003-2005)$. A subsequent inspection of the ponds confirmed the presence of a number of individuals, but no tadpoles were found.

Fejervaria limnocharis sensu lato is known to be a composite of several morphologically similar but genetically distinct species (e.g., Dubois 1987, Toda et al. 1998, Dubois and Ohler 2002). It is widespread throughout the Asian region, ranging from China to Nepal, Pakistan, India, Sri Lanka through to Japan, Taiwan, Philippines, Indonesia, Cambodia, Thailand, and Malaysia (Toda et al. 1997, Sumida et al. 2002, Frost 2004). A member of this species complex is currently well established on some islands of the Ryukyus, including a few oceanic islands (Ota et al. 2004).

To determine the specific identity and origin of the Guam samples, genetic investigations are essential.

Microbyla pulcbra Hallowell, 1861 (Family Microhylidae), Marbled Pigmy Frog

This species was initially recorded from Dandan (Figure 1), where three individuals were observed around the periphery of a pond (22 March 2004), two of which were collected. It was then located at Inarajan (26 March 2004 [Figure 2C]), approximately 5 $\mathrm{km}$ distant, where a single individual was observed in a mud depression made by ungulates at the pond's edge. It has not since been recorded at any other location, either as adults or tadpoles.

Microbyla pulchra is found throughout India and Sri Lanka, and Southeast Asia including Indochina and southern China (Dubois 1987, Frost 2004).

\section{Unsuccessfully Established Species}

Eleutherodactylus coqui Thomas, 1966 (Family Leptodactylidae), Coquí Frog

This species was first reported (November 2003) from calls heard by a member of the public at Tumon (Figure 1), less than $50 \mathrm{~m}$ from a plant nursery. A single call was heard periodically over several weeks, but no speci- men was caught. The reporter recognized the call as the same as those heard in Puerto Rico. In 2004, two specimens were collected in central Guam by the Guam Division of Agriculture and Wildlife Resources (DAWR, unpubl. data).

Eleutherodactylus coqui is native only to Puerto Rico but has been introduced to Florida (Meshaka et al. 2004) and from there to Hawai'i in the mid- to late 1990s (Kraus et al. 1999, Kraus and Campbell 2002). Hawai'i is the suspected origin of the individuals found on Guam.

Kaloula pulchra Gray, 1831 (Family Microhylidae), Malayan Narrow-Mouthed Toad

A single individual was discovered by military personnel in a cargo plane arriving from Thailand at Andersen Air Force Base (Figure 1) on 3 October 2003. The species has not been recorded on the island since.

Kaloula pulchra is found throughout Southeast Asia including Cambodia, Indonesia, Laos, Malaysia, Myanmar, Singapore, Thailand, and Vietnam, as well as China, Nepal, and northeastern India (Naik and Vinod 1996, Frost 2004). Flower (1896, 1899) suggested that the Singapore population is introduced. The species seems also to have been introduced to Borneo and Sulawesi (Parker 1934, Matsui 1979, Inger and Stuebing 1997) and recently to Taiwan (Lue et al. 1999).

\section{DISCUSSION}

Vertebrate species have been introduced to Guam from a variety of locations around the globe including North America, Micronesia, New Guinea, the Philippines, other parts of Asia, Australia, and Hawai'i (Chernin 1979, Eldredge 1988, Rodda et al. 1992, Fritts and Rodda 1998) (Table 1). Before western settlement, 13 species of reptiles but no amphibians were found on the island (Rodda and Fritts 1992). Bufo marinus was the first frog to be introduced, in 1937 (Chernin 1979), followed by Litoria fallax in 1968 (Eldredge 1988). With the addition of the species newly reported herein, the number of breeding frog species on Guam has risen to at least five. Except for B. marinus, all introductions (suc- 
TABLE 1

Herpetological Introductions to Guam (1800-2005)

\begin{tabular}{|c|c|c|c|c|c|}
\hline Taxa & $\begin{array}{c}\text { Year } \\
\text { Detected }\end{array}$ & Release & Status $^{a}$ & $\begin{array}{l}\text { Probable } \\
\text { Origin }\end{array}$ & References \\
\hline \multicolumn{6}{|l|}{ Frogs and Toads } \\
\hline Bufo marinus (marine toad) & 1937 & Intentional & Established & Hawai'i & $\begin{array}{l}\text { Anon. (1940), Townes (1946), } \\
\text { Chernin (1979), Easteal (1981) }\end{array}$ \\
\hline Eleutherodactylus coqui (coquí frog) & 2003 & Accidental & Absent & Hawai'i & DAWR, unpubl. data \\
\hline Eleutherodactylus planirostris (greenhouse frog) & 2003 & Unknown & Established & Hawaici & This study \\
\hline Fejervarya cancrivora (crab-eating frog) & 2005 & Unknown & Present & SE Asia & This study \\
\hline Fejervarya limnocharis sensu lato (Indian rice frog) & 2003 & Unknown & Present & SE Asia & This study \\
\hline Kaloula pictab (painted narrow-mouthed frog) & 1990 & Accidental & $\begin{array}{l}\text { No colonization } \\
\text { resulted }\end{array}$ & Philippines & McCoid (1993) \\
\hline Kaloula pulchra ${ }^{b}$ (Malayan narrow-mouthed frog) & 2003 & Accidental & $\begin{array}{l}\text { No colonization } \\
\text { resulted }\end{array}$ & SE Asia & This study \\
\hline Litoria fallax (eastern dwarf treefrog) & 1968 & Unknown & Established & Australia & Falanruw (1976), Eldredge (1988) \\
\hline Microbyla pulchra (marbled pigmy frog) & 2004 & Unknown & Present & SE Asia & This study \\
\hline Polypedates leucomystax ${ }^{b}$ (whipping frog) & 1993 & Unknown & $\begin{array}{l}\text { No colonization } \\
\text { resulted }\end{array}$ & Thailand & Wiles (2000) \\
\hline Polypedates megacephalus (Hong Kong whipping frog) & 2004 & Unknown & Established & SE Asia & This study \\
\hline Pseudacris regilla ${ }^{b}$ (pacific treefrog) & 1989,2005 & Accidental & $\begin{array}{l}\text { No colonization } \\
\text { resulted }\end{array}$ & NW USA & McCoid (1993); DAWR, unpubl. data \\
\hline Rana guentheri (Günther's amoy frog) & 2001 & Accidental & Established & E Asia & This study \\
\hline \multicolumn{6}{|l|}{ Reptiles } \\
\hline Anolis carolinensis (green anole) & $1950 \mathrm{~s}$ & Intentional & Established & SE USA & $\begin{array}{l}\text { Moore (1977), Eldredge (1988), } \\
\text { Mayer and Lazell (1992) }\end{array}$ \\
\hline Boiga irregularis (brown tree snake) & 1950 & Accidental & Established & Admiralty Islands & $\begin{array}{l}\text { Savidge (1987), Fritts (1988), Rodda } \\
\text { et al. (1992) }\end{array}$ \\
\hline Carlia ailanpalai (curious skink) & 1968 & Unknown & Established & Admiralty Islands & Rodda et al. (1991), Zug (2004) \\
\hline Chelydra serpentina (common snapping turtle) & 1997 & Unknown & Unknown & USA & Leberer (2003) \\
\hline Chinemys reevesii (Chinese three-keeled pond turtle) & Early 1990s & Unknown & Unknown & E Asia & Leberer (2003) \\
\hline Chrysemys picta ${ }^{b}$ (painted turtle) & 1990 & Accidental & $\begin{array}{l}\text { No colonization } \\
\text { resulted }\end{array}$ & USA & McCoid (1993) \\
\hline Gekko gecko ${ }^{b}$ (tokay gecko) & 1983 & Accidental & $\begin{array}{l}\text { No colonization } \\
\text { resulted }\end{array}$ & Philippines & McCoid (1993) \\
\hline Iguana iguana $^{b}$ (green iguana) & 1983 or 1984 & Accidental & $\begin{array}{l}\text { No colonization } \\
\text { resulted }\end{array}$ & Unknown & McCoid (1993) \\
\hline Kinosternon sp. (mud turtle) & $1970 \mathrm{~s}$ & Unknown & $\begin{array}{l}\text { No colonization } \\
\text { resulted }\end{array}$ & Americas & Leberer (2003) \\
\hline Lamprolepis smaragdina (green tree skink) & $1960 \mathrm{~s}$ & Intentional & Absent & Yap & Eldredge (1988) \\
\hline
\end{tabular}




\begin{tabular}{|c|c|c|c|c|c|}
\hline Mabuya multifasciata ${ }^{b}$ (many-lined sun skink) & 1999 & Accidental & $\begin{array}{l}\text { No colonization } \\
\text { resulted }\end{array}$ & Philippines & Wiles (2000) \\
\hline Mabuya sp. ${ }^{b}$ & 1970 & Accidental & $\begin{array}{l}\text { No colonization } \\
\text { resulted }\end{array}$ & Caroline Islands & Wiles (2000) \\
\hline Ocadia sinensis (Chinese striped-neck turtle) & Early 1990s & Unknown & Unknown & E Asia & Leberer (2003) \\
\hline Perocbirus atelesb, (Micronesian gecko) & 1991 & Accidental & $\begin{array}{l}\text { No colonization } \\
\text { resulted }\end{array}$ & Chuuk & Wiles (2000) \\
\hline Sceloporus occidentalis ${ }^{b}$ (western fence lizard) & 1992 & Accidental & $\begin{array}{l}\text { No colonization } \\
\text { resulted }\end{array}$ & California & Wiles (2000) \\
\hline Trachemys scripta elegans (red-eared slider) & $1950 \mathrm{~s}$ & Unknown & Present & SE USA & McCoid $(1993,1999)$ \\
\hline
\end{tabular}

a Status is that for wild stocks on Guam (2005) to the best of the authors' knowledge. Species are listed as "present" if the population's recruitment is unknown or inadequately documented.

${ }^{b}$ Introduced individuals that were intercepted and destroyed in cargo or on board cargo vessels.
${ }^{c}$ This species is native to Guam but had been extirpated from the island (Rodda et al. 1991) by the time of this introduction. 
cessful and unsuccessful) were most likely accidental.

The recently introduced anurans arrived on Guam without most of their native associates, including predators, competitors, or parasites. There are no native amphibian species on Guam, so an obvious ecological consequence of their invasion is a reduction in invertebrate abundance and diversity (Stewart and Woolbright 1996, Beard et al. 2003). If the incursion of anurans causes unnaturally high predation pressure on especially vulnerable native species such as tree snails (Partula gibba and Partula radiolata), recovery of those populations may not be possible (e.g., Cowie 1992, 2001, Hadfield et al. 1993).

Just as invasive anurans can be predators in Guam's ecosystem, so too they can be prey. Following the extirpation of the majority of Guam's endotherms, B. irregularis must now depend more heavily on diurnal, terrestrial species of lizards that are comparatively reclusive at night (Fritts and Rodda 1998, Boyarski 2005). With the addition of palatable nocturnal anurans (e.g., Minton and Dunson 1978, Greene 1989, Shine 1991), accessibility to substantial active prey during the snakes' primary foraging period could greatly increase. On Guam, the snake has consumed E. planirostris in captivity (C.L.T., unpubl. data) and has been observed preying on unidentified Rana sp. in the wild (G. Acosta, Guam Department of Agriculture, unpubl. data). Further, a number of prey sizes attractive to $B$. irregularis are now represented by the new frog species, each filling a portion of the void in the prey size continuum created by the extirpation of most of Guam's birds. Ontogenetic shifts in consumption based on prey size and type in B. irregularis are well documented; juvenile snakes prey on small ectotherms such as lizards, and mature snakes prey on larger endotherms such as birds and rats (Savidge 1988, Greene 1989). Through the incursion of anurans covering sizes from 2 to $10 \mathrm{~g}$ (E. planirostris, E. coqui, and L. fallax), 10 to $30 \mathrm{~g}$ (P. megacephalus, M. pulchra), and greater than $30 \mathrm{~g}$ ( $F$. limnocharis sensu lato, $F$. cancrivora, and $R$. guentheri), all prey sizes, particularly those crucial for small snakes, are potentially available. Although some introduced frogs are relatively small, they can be locally common and their reproductive potential high enough to withstand strong predation pressure (Kraus et al. 1999). Such abundant populations are a key food source sufficient to supply increasing snake population densities. Moreover, E. planirostris and $E$. coqui's direct development will allow them to potentially colonize a large proportion of the island, including the north, because they do not require standing water to breed. The pond species, however, will remain limited to the southern half of the island, where surface water provides breeding sites. Thus, anuran prey for small snakes would likely be available islandwide and in most habitats.

The threat that invasion poses to Guam's ecosystem also threatens the island's socioeconomic interests in a number of ways. Guam's primary industry is tourism, which accounts for approximately $60 \%$ of its economy (Whitman 2003). Eleutherodactylus coqui is known for its piercing chirp, and choruses have been recorded to exceed 70 decibels (Kraus et al. 1999). Residents and tourists of areas of Hawai'i plagued with the species experience disturbance and sleep problems as a direct result of deafening choruses (Kraus and Campbell 2002). If populations of $E$. coqui become established on Guam, the economic repercussions to the tourism industry could be substantial, as has been the case in Hawai'i (Kraus et al. 1999, Kraus and Campbell 2002). In addition to the impact upon tourism, nonindigenous frogs could negatively impact freshwater fisheries production and the horticulture industry by forcing the implementation of stricter quarantine measures that could decrease imports to Guam.

The number of individuals in each introduction and the overall frequency of introductions have been found to affect the probability of a species establishing (Veltman 1996, Kolar and Lodge 2001). For example, the rapid expansion of the Guam population of $R$. guentheri may have been facilitated by multiple introductions over time that increased reproductive output. It stands to rea- 
son that high frog densities on Guam could increase the probability of their transport to Guam's trading partners, such as the Northern Mariana Islands, Federated States of Micronesia, and Hawai' $i$. If these frogs provide a substantial increase in available prey, and this in turn leads to higher densities of B. irregularis on Guam, then there will be a greater probability of snakes successfully entering cargo and being transported to new locations. Once in these new locations, $B$. irregularis is likely to proliferate if the right-sized prey, such as frogs, are abundant. It is therefore important both to reduce the risk of introduction and reintroduction of anurans to Guam and neighboring Pacific islands, and to control the spread and reduce the numbers of established anuran populations on Guam.

Control, containment, and future prevention of anuran introductions are important issues that are beginning to be addressed on Guam. Recently, the Guam Department of Agriculture established a Plant Inspection Station that has decreased the risk of alien flora and fauna entering Guam through live plant shipments. Restrictions on cargo originating from Hawai'i have helped reduce the entry of Eleutherodactylus via plant material. Temporary containment of imported plants, inspection of cargo, the use of alternative treatments such as citric acid sprays and hot water for foliage and soil, the trade of bare-rooted rather than soil-rooted plants, and tighter phytosanitary certificate conditions associated with high-risk cargo are all examples of a multifaceted quarantine and containment initiative undertaken by local government agencies. In addition, Guam Division of Aquatic and Wildlife Resources launched a communication and outreach program in March 2005 aimed at educating the public in detecting and reporting the occurrence of frogs, especially E. coqui.

\section{VOUCHER MATERIALS EXAMINED}

USNM (Smithsonian National Museum of Natural History), врвм (Bernice Pauahi Bishop Museum), kUz (Kyoto University Museum), вSFs (U.S. Geological Survey/
Colorado State University Brown Tree Snake Project).

Eleutherodactylus coqui: (Tumon) вsFs 9321; (Manengon) вSFS 9323.

Kaloula pulchra: (Andersen Air Force Base) USNM 561142.

Pseudacris regilla: (“Guam”) вsғs 9352.

Fejervarya cancrivora: (Fadian Point, near Mangilao) вSFs 9304; ("southern Guam") врвм 21288; (“southern Guam”) кUz R57996; (Ordot School, Mangilao) kUz R57995 and USNM 563050; (Mangilao) вРвм 21336.

Fejervarya cf. limnocharis: (Pulantat) USNM 563051.

Microbyla pulcbra: (Dandan) вsfs 9324 and BSFS 9325 .

Eleutherodactylus planirostris: (Tumon) USNM 561138-561141, вРвм 18229-18234, and вSFS 9253-9258.

Polypedates megacephalus: (Dandan) USNM 563052, врвм 21284-21285, вSFS 92629274, вSFS 9276-9282.

Rana guentheri: (Inarajan) USNM 561143, USNM 563049 and metamorphs BSFS 9228, BSFS 9230, вSFS 9235-9237, USNM 561144561145, врвм 18235; (Molojloj Village $\mathrm{N}$ of Dandan) врвм 21286-21287.

\section{ACKNOWLEDGMENTS}

We thank Earl Campbell III, Jeff Cepeda, Brian Feeley, Dustin Janeke, Linda Laracuente, Jeffrey Quitugua, Haldre Rogers, Peter San Nicolas, and Rick Seidel for collection, information, and, in some cases, discovery of the frogs in Guam. We are grateful to Steve Gotte, Fred Kraus, Roy McDiarmid, Hidetoshi Ota, and George Zug for their invaluable contribution to species identification. The Bernice Pauahi Bishop Museum's Division of Natural Sciences, Smithsonian National Museum of Natural History's Division of Amphibians and Reptiles, Kyoto University Museum, and The U.S. Geological Survey/Colorado State University Brown Tree Snake Project archived specimens as indicated in the text. We thank Richard Bischof for his assistance in preparing some of the figures. Fred Kraus, Teri Kman, Bjorn Lardner, Ross Sadlier, Hidetoshi Ota, and an 
anonymous reviewer suggested improvements to the manuscript.

\section{Literature Cited}

Anonymous. 1940. The toad introduced into Guam in 1937. Guam Rec. 17:68-84.

Beard, K. H., A. K. Eschtruth, K. A. Vogt, D. J. Vogt, and F. N. Scatena. 2003. The effects of the frog Eleutherodactylus coqui on invertebrates and ecosystem processes at two scales in the Luquillo Experimental Forest, Puerto Rico. J. Trop. Ecol. 19:607-617.

Belcher, C. A. 1998. Susceptibility of the tiger quoll, Dasyurus maculatus, and the eastern quoll, D. viverrinus, to 1080 poisoned baits in control programmes for vertebrate pests in eastern Australia. Wildl. Res. 25:33-40.

Boyarski, V. L. 2005. Trappability and activity of juvenile brown treesnakes (Boiga irregularis) on Guam. M.S. thesis, Colorado State University, Fort Collins.

Brown, W. S., and A. C. Alcala. 1970. The zoogeography of the herpetofauna of the Philippine Islands, a fringing archipelago. Proc. Calif. Acad. Sci. 38:105-111.

Burnett, S. 1997. Colonizing cane toads cause population declines in native predators: Reliable anecdotal information and management implications. Pac. Conserv. Biol. 3:65-72.

Cadi, A., and P. Joly. 2003. Competition for basking places between the endangered European pond turtle (Emys orbicularis galloitalica) and the introduced red-eared slider (Trachemys scripta elegans). Can. J. Zool. 81:1392-1398.

Case, T. J., and D. T. Bolger. 1991. The role of introduced species in shaping the distribution and abundance of island reptiles. Evol. Ecol. 5:272-290.

Chernin, M. I. 1979. Population dynamics and reproductive strategy of Bufo marinus (L.) on Guam. M.S. thesis, University of Guam, Mangilao.

Costin, A. B., and R. M. Moore. 1960. The effects of rabbit grazing on the grasslands of Macquarie Island. J. Ecol. 48: 729-732.
Cowie, R. H. 1992. Evolution and extinction of Partulidae endemic Pacific island land snails. Philos. Trans. R. Soc. Lond. B Biol. Sci. 335:167-191.

2001. Invertebrate invasions on $\mathrm{Pa}$ cific islands and the replacement of unique native faunas: A synthesis of the land and freshwater snails. Biol. Invasions 3:119136.

Dickman, C. R. 1996. Impact of exotic generalist predators on the native fauna of Australia. Wildl. Biol. 2:185-195.

Dubois, A. 1987. Miscellanea taxinomica batrachologica. Alytes 6:1-9.

Dubois, A., and A. Ohler. 2002. Systematics of Fejervarya limnocharis (Gravenhorst, 1829) (Amphibia, Anura, Ranidae) and related species. 2. Morphological and molecular variation in frogs from the Greater Sunda Islands (Sumatra, Java, Borneo) with the definition of two species. Alytes 19:528.

Eason, C. T., L. Milne, M. Potts, G. Morriss, G. R. Wright, and G. Sutherland. 1999. Secondary and tertiary poisoning risks associated with brodifacoum. N. Z. J. Ecol. 23:219-224.

Easteal, S. 1981. The history of introductions of Bufo marinus (Amphibia: Anura); a natural experiment in evolution. Biol. J. Linn. Soc. 16:93-113.

Eldredge, L. G. 1988. Case studies of the impacts of introduced animal species on renewable resources in the U.S.-affiliated Pacific islands. Pages 26-46 in B. D. Smith, ed. Topic reviews on insular resource development in the Pacific U.S.affiliated islands. Univ. Guam Mar. Lab. Tech. Rep. 88.

Falanruw, M. V. C. 1976. Savanna, old field roadsides. Life on Guam. Guam Department of Education, Hagåaña.

Flower, S. S. 1896. Notes on a collection of reptiles and batrachians made in the Malay Peninsula in 1895-96; with a list of species recorded from that region. Proc. Zool. Soc. Lond. 1896:856-914.

. 1899. Notes on a second collection of batrachians made in the Malay Peninsula and Siam from November 1896 to September 1898 , with a list of species re- 
corded from those countries. Proc. Zool. Soc. Lond. 1899:885-916.

Fritts, T. H. 1988. The brown tree snake, Boiga irregularis, a threat to Pacific Islands. U.S. Fish Wildl. Serv. Biol. Rep. 88.

Fritts, T. H., and G. H. Rodda. 1998. The role of introduced species in the degradation of island ecosystems: A case history of Guam. Annu. Rev. Ecol. Syst. 29:113140.

Frost, D. R. 2004. Amphibian species of the world: An online reference. V. 3.0. http:// research.amnh.org/herpetology/amphibia/ index.php. American Museum of Natural History, New York.

Geering, W. A., A. Forman, and M. J. Nunn. 1995. Exotic diseases of animals: A field guide for Australian veterinarians. Aust. Gov. Publ. Ser., Canberra.

Greene, H. W. 1989. Ecological, evolutionary, and conservation implications of feeding biology in Old World cat snakes, genus Boiga (Colubridae). Proc. Calif. Acad. Sci. 46:193-207.

Hadfield, M. G., S. E. Miller, and A. H. Carwile. 1993. The decimation of endemic Hawaiian tree snails by alien predators. Am. Zool. 33:610-622.

Inger, R. F., and R. B. Stuebing. 1997. A field guide to frogs of Borneo. Nat. Hist. Publ., Kota Kinabalu, Malaysia.

Kolar, C. S., and D. M. Lodge. 2001. Progress in invasion biology: Predicting invaders. Trends Ecol. Evol. 16:199-204.

Kraus, F., and E. W. Campbell. 2002. Human-mediated escalation of a formerly eradicable problem: The invasion of $\mathrm{Ca}-$ ribbean frogs in the Hawaiian Islands. Biol. Invasions 4:327-332.

Kraus, F., E. W. Campbell, A. Allison, and T. Pratt. 1999. Eleutherodactylus frog introductions to Hawaii. Herpetol. Rev. 30:2125.

Leberer, T. 2003. Records of freshwater turtles on Guam, Mariana Islands. Micronesica 35-36:649-652.

Lue, K. Y., M. C. Tu, and G. Shang. 1999. Guide to amphibians and reptiles of Taiwan. Nature Conservation Association of Republic of China, Taipei.

Marks, C. A., C. Hackman, F. Busana, and F.
Gigliotti. 2000. Assuring that 1080 toxicosis in the red fox (Vulpes vulpes) is humane: Fluoroacetic acid (1080) and drug combinations. Wildl. Res. 27:483-494.

Matsui, M. 1979. Amphibians of Sabah. I. Systematic and natural history notes. Contrib. Biol. Lab. Kyoto Univ. 25:303-346.

Mayer, G. C., and J. D. Lazell Jr. 1992. Identity and distribution of the introduced $A n$ olis lizard of Hawaii and other Pacific islands. Suppl. Bull. Ecol. Soc. Am. 73:265.

McCoid, M. J. 1993. The "new" herpetofauna of Guam, Mariana Islands. Herpetol. Rev. 24:16-17.

1999. Established exotic reptiles and amphibians of the Mariana Islands. Pages 453-459 in G. H. Rodda, Y. Sawai, D. Chiszar, and H. Tanaka, eds. Problem snake management: The habu and the brown treesnake. Cornell University Press, Ithaca, New York.

McCoid, M. J., and C. Kleberg. 1995. Nonnative reptiles and amphibians. Pages 433-437 in E. T. LaRoe, G. S. Farris, C. E. Puckett, P. D. Doran, and M. J. Mac, eds. Our living resources: A report to the nation on the distribution, abundance, and health of U.S. ecosystems. U.S. Dep. Inter., Nat. Biol. Ser., Washington, D.C.

Menzies, J. I. 1996. Unnatural distribution of fauna in the East Malesian region. Pages 31-38 in D. J. Kitchener and A. Suyanto, eds. Proceedings of the First International Conference on Eastern Indonesian-Australian Vertebrate Fauna, Manado, Indonesia, 22-26 November 1994.

Meshaka, W. E., Jr., B. P. Butterfield, and J. B. Hauge. 2004. Exotic amphibians and reptiles of Florida. Krieger Publishing Company, Melbourne, Florida.

Minton, S. A., and W. A. Dunson. 1978. Observations on the Palawan mangrove snake, Boiga dendrophila multicincta (Reptilia, Serpentes, Colubridae). J. Herpetol. 12:107108.

Moore, P. H. 1977. An ecological survey of pristine terrestrial communities on Guam. Pages 1-45 in D. A. Bonvouloir and P. D. McMakin, eds. Guam coastal management program technical reports. Vol. 1. Gov- 
ernment of Guam Bureau of Planning, Agana.

Moore, P. H., R. A. Griffiths, R. M. O'Brien, A. Murphy, and D. Jay. 2004. Induced defenses in an endangered amphibian in response to an introduced snake predator. Oecologia (Berl.) 141:139-147.

Naik, Y. M., and K. R. Vinod. 1996. Amphibian fauna of Gujarat: An updated checklist with key to the identification of species. J. Anim. Morphol. Physiol. 43:191-194.

Orlov, N. L., R. W. Murphy, N. B. Ananjeva, S. A. Ryabov, A. Sergei, and H. T. Cuc. 2002. Herpetofauna of Vietnam, a checklist. Part I. Amphibia. Russ. J. Herpetol. 9:81-104.

Ota, H., Mi. Toda, G. Masunaga, A. Kikukawa, and Ma. Toda. 2004. Feral populations of amphibians and reptiles in the Ryukyu Archipelago, Japan. Glob. Environ. Res. 8:133-143.

Parker, H. W. 1934. A monograph of the frogs of the family Mocrohylidae. British Museum of Natural History, London.

Paulay, G. 1994. Biodiversity on oceanic islands: Its origin and extinction. Am. Zool. 34:134-144.

Pimm, S. L. 1987. Determining the effects of introduced species. Trends Ecol. Evol. 2:106-108.

Poulin, B., G. Lefebvre, R. Ibanez, C. Jaramillo, C. Hernandez, and A. S. Rand. 2001. Avian predation upon lizards and frogs in a neotropical forest understory. J. Trop. Ecol. 17:21-40.

Priddel, D., and N. Carlile. 1998. Conservation of the endangered Gould's petrel Pterodroma leucoptera leucoptera. Pac. Conserv. Biol. 3:322-329.

Rodda, G. H., and T. H. Fritts. 1992. The impact of the introduction of the colubrid snake Boiga irregularis on Guam's lizards. J. Herpetol. 26:166-174.

Rodda, G. H., T. H. Fritts, and P. I. Conry. 1992. Origin and population growth of the brown tree snake, Boiga irregularis, on Guam. Pac. Sci. 46:46-57.

Rodda, G. H., T. H. Fritts, and J. D. Reichel. 1991. The distributional patterns of reptiles and amphibians in the Mariana Islands. Micronesica 24:195-210.
Rosenzweig, M. L. 1981. A theory of habitat selection. Ecology 62:327-335.

Rosenzweig, M. L., and R. H. MacArthur. 1963. Graphical representation and stability conditions of predator-prey interactions. Am. Nat. 97:209-223.

Savidge, J. A. 1984. Guam: Paradise lost for wildlife. Biol. Conserv. 30:305-317.

. 1987. Extinction of an island forest avifauna by an introduced snake. Ecology 68:660-668.

- 1988. Food habits of Boiga irregularis, an introduced predator on Guam. J. Herpetol. 22:275-282.

Schwartz, A. 1974. Eleutherodactylus planirostris (Cope). Cat. Am. Amphib. Reptiles 154:1-4.

Shine, R. 1991. Strangers in a strange land: Ecology of Australian colubrid snakes. Copeia 1991:120-131.

Short, J., J. E. Kinnear, and A. Robley. 2002. Surplus killing by introduced predators in Australia: Evidence for ineffective antipredator adaptations in native prey species? Biol. Conserv. 103:283-301.

Stewart, M., and L. Woolbright. 1996. Amphibians. Pages 274-320 in D. Reagan and R. Waide, eds. The food web of a tropical rain forest. University of Chicago Press, Chicago.

Sumida, M., Y. Kondo, Y. Kanamori, and M. Nishioka. 2002. Inter- and intraspecific evolutionary relationships of the rice frog Rana limnocharis and the allied species $R$. cancrivora inferred from crossing experiments and mitochondrial DNA sequences of the $12 \mathrm{~S}$ and $16 \mathrm{~S}$ rRNA genes. Mol. Phylogenet. Evol. 25:293-305.

Toda, M., M. Matsui, M. Nishida, and H. Ota. 1998. Genetic variation among Southeast and East Asian populations of Rana limnocharis (Amphibia: Anura), with special reference to sympatric cryptic species in Java. Zool. Sci. (Tokyo) 15:607-613.

Toda, M., M. Nishida, M. Matsui, G. F. $\mathrm{Wu}$, and H. Ota. 1997. Allozyme variation among East Asian populations of the Indian rice frog, Rana limnocharis (Amphibia: Anura). Biochem. Syst. Ecol. 25: 143-159. 
Townes, H. K. 1946. Entomology. Part 1. Non-agricultural plants. Econ. Surv. Micronesia 12:1-53.

Veltman, C. J. 1996. Correlates of introduction success in exotic New Zealand birds. Am. Nat. 147:542-557.

Whitman, F. 2003. Halting Guam's downward spiral; financial crisis requires drastic measures. Pac. Mag. 2003:1-3.

Wiles, G. J. 2000. Recent records of reptiles and amphibians accidentally transported to Guam, Mariana Islands. Micronesica 32:285-287.

Zhao, E., and K. Adler. 1993. Herpetology of China. Society for the Study of Amphibians and Reptiles, Oxford, Ohio.

Zug, G. R. 2004. Systematics of the Carlia "fusca" lizards (Squamata: Scincidae) of New Guinea and nearby islands. Bishop Mus. Bull. Zool. 5:1-83. 
